\title{
POLA MAKAN DAN AKTIVITAS FISIK PADA PASIEN DIABETES MELLITUS TIPE 2 DI RUMAH SAKIT PANCARAN KASIH MANADO
}

\author{
I Made Djendra ${ }^{1}, M_{\text {Mksin Pasambuna }}{ }^{1}$,dan Siani Pintan ${ }^{1}$ \\ 1 Jurusan Gizi Poltekes Kemenkes Manado \\ email koresondens : dedjendra@gmail.com
}

\begin{abstract}
The purpose of this study was to determine the relationship between diet and physical activity on blood sugar levels of Type 2 Diabetes Mellitus patients at Pancaran Kasih Hospital in Manado City and the results of this study can be used as input material for patients to be able to maintain their diet and regulate physical activity to control blood sugar levels remain at normal limits. Diabetes mellitus is a chronic condition where the body cannot or does not produce insulin optimally. The study design used was a type of observational study with a cross sectional approach to determine the relationship between risk factors and disease. In this study used 2 independent variables, namely diet and physical activity and the dependent variable Diabetes Mellitus. The method of taking samples is using purposive sampling in accordance with the proposed inclusion and exclusion criteria. The samples needed in this study were 41 people determined by the Slovin formula. From the results of this study note that eating patterns have a value of $p=0.00, p<0.05$ which means there is a significant relationship with eating patterns with blood sugar levels of Type 2 Diabetes Mellitus patients. Results of physical activity $p=0.03, p<$ 0.05 which means there is a significant relationship between physical activity and blood sugar levels in Type 2 Diabetes Mellitus patients at Pancaran Kasih Hospital in Manado City.
\end{abstract}

\section{Keywords: Diet, Physical Activity, Diabetes mellitus}

Berdasarkan peta International Diabetes Federation (IDF) pada tahun 2011 menyatakan bahwa Indonesia menempati urutan ke 10 jumlah penderita diabetes, dan diperkirakan pada tahun 2030 Indonesia akan naik dengan menempati urutan ke-9 jumlah penderita Diabetes Melitus. IDF memperkirakan bahwa sebanyak 183 juta orang tidak menyadari bahwa mereka mengidap Diabetes Melitus. Sebesar $80 \%$ orang dengan Diabetes Melitus tinggal di negara berpenghasilan rendah dan menengah (IDF, 2011).

Selanjutnya pada tahun 2015, peta IDF menunjukan perkiraan jumlah orang dengan diabetes di seluruh dunia mencapai 415 juta orang, dan diperkirakan akan naik hingga 642 juta orang pengidap Diabetes Melitus pada tahun 2040. Untuk jumlah penderita Diabetes Melitus perwilayah yang memiliki jumlah penderita terbanyak yaitu bagian Pasific Barat dengan jumlah 153,2 juta penderita diabetes melitus. Untuk urutan kedua terbanyak adalah Asia Tenggara dengan jumlah 78,3 juta penderita Diabetes Melitus (IDF, 2015).

Menurut Riset Kesehatan Dasar pada tahun 2013, prevalensi Diabetes Melitus di Indonesia mencapai $2,1 \%$. Provinsi yang memiliki prevalensi tertinggi yang ada pada provinsi Sulawesi Tengah yaitu mencapai 3,7\%, untuk provinsi kedua dengan prevalensi tertinggi ada pada Sulawesi Utara yaitu $3,6 \%$ dan untuk yang dan yang ketiga yaitu provinsi Sulawesi Selatan dengan prevalensi 3,4\% (Balitbangkes, 2013). 


\section{GIZIDO Volume 11 No.2 November 2019 Pola Makan I Made Djendra dkk}

Survei Kesehatan Rumah Tangga (SKRT) 2001 mendapatkan prevalensi diabetes melitus pada penduduk usia 25-64 tahun di Jawa dan Bali sebesar 7,5\%. Riset Kesehatan Dasar (Riskesdas) tahun 2007 dan 2013 melakukan wawancara untuk menghitung proporsi diabetes melitus pada usia 15 tahun keatas. Didefinisikan sebagai Diabetes Melitus jika pernah didiagnosis menderita kencing manis oleh dokter atau belum pernah didiagnosis menderita kencing manis oleh dokter tetapi dalam 1 bulan terakhir mengalami gejala sering lapar, sering haus, sering buang air kecil dengan jumlah banyak dan berat badan menurun. Hasil wawancara tersebut mendapatkan bahwa proporsi Diabetes Melitus pada Riskesda 2013 meningkat hampir duakali lipat dibandingkan dengan 2007. (Kemenkes, 2014)

\section{METODE}

Jenis penelitian yang bersifat observasional dengan rancangan crosssectional. Penelitian ini dilakukan di Rumah Sakit Umum Pancaran Kasih Manado pada tanggal 03 Mei - 18 Mei 2019. Variabel dalam penelitian ini terdiri atas variabel bebas adalah pola makan dan aktifitas fisik, dan variabel terikat adalah Diabetes Mellitus tipe 2. Populasi dalam penelitian ini adalah pasien diabetes melitus tipe II yang dirawat jalan. Teknik pengambilan sampel menggunakan purposivesampling. Jumlah sampel adalah 41orang, sampel yang diambil berdasarkan kriteria inklusi yaitu: pasien dengan diagnos DM tipe 2, bersedia menjadi responden dan hadir saat penelitian dilakukan.

Instrumen yang digunakan adalah formulir identitas responden, kuesioner pola makan semi ffq dan kuesioner aktifitas fisik. Data diambil melalui wawancara dengan data primer yangdikumpulkan adalah identitas responden, jenis dan frekuensi makan dan aktifitas fisik yang dilakukan responden. Data sekunder yaitu gambaran umum rumah sakit diperoleh dari buku laporan RS, kadar gula darah diperoleh dari hasil laboratorium yang di bawa oleh responden. Uji statistik yang digunakan yaitu Uji Fisher Exact Test dengan $\alpha=0,05$

\section{HASIL}

Hasil penelitian ini, responden terbanyak berumur 60-69 tahun dengan jumlah 17 orang $(41,5 \%)$ dan 1 orang berusia $>70$ tahun $(2,4 \%)$. Pada tabel distribusi di atas dapat diketahui bahwa dari 41 orang sampel jenis kelamin laki-laki berjumlah 15 orang (36,6\%) dan perempuan 26 orang $(63,4 \%)$. Diketahui bahwa dari 41 orang sampel lulusan SMA/SMK memiliki jumlah lebih banyak yaitu 14 orang $(34,1 \%)$ dan lulusan perguruan tinggi 5 orang (12,2\%). Distribusi di atas dapat diketahui bahwa dari 41 orang sampel yang memilik jumlah terbanyak adalah ibu rumah tangga dengan jumlah 18 orang $(43,9)$ dan yang memiliki kadar gula darah normal atau kurang dari $200 \mathrm{mg} / \mathrm{dl}$ berjumlah 13 orang $(31,7 \%)$ dan kadar gula darah lebih atau yang memiliki kadar gula darah lebih dari $200 \mathrm{mg} / \mathrm{dl}$ berjumlah 28 orang $(68,3 \%)$.

Hasil penelitian pun diketahui bahwa dari 41 orang sampel yang memiliki pekerjaan sebagai petani berjumlah 2 orang dengan kadar gula darah lebih 2 orang. Pekerja swasta memiliki jumlah 5 orang dengan kadar gula darah normal 3 orang. Pekerja wiraswasta berjumlah 8 orang dengan kadar gula darah lebih 8 orang. Ibu rumah tangga memiliki jumlah 18 orang dengan kadar gula darah lebih 14 orang. Pekerja PNS berjumlah 6 orang dengan kadar gula darah lebih maupun normal ada 3 orang dan 
lainnya memiliki jumlah 2 orang dengan kadar gula darah lebuh dan normal berjumlah 1 orang.

Demikian pula diketahui bahwa dari 41 orang sampel yang memiliki pendidikan SD berjmlah 11 orang dengan kadar gula darah lebih 8 orang. Pendidikan SMP berjumlah 11 orang dengan kadar gula darah lebih 6 orang. Untuk pendidikan SMA/SMK berjumlah 14 orang denan kadar gula darah lebih 12 orang dan untuk pendidikan S1 berjumlah 5 orang dengan kadar gula darah normal 3 orang, dan berjenis kelamin lakilaki berjumlah 15 orang dengan kadar gula darah lebih 8 orang, dan untuk jenis kelamin perempuan berjumlah 26 orang denan kadar gula darah lebih 20 orang.

Tabel 1. Hubungan Pola Makan dengan Kadar Gula Darah

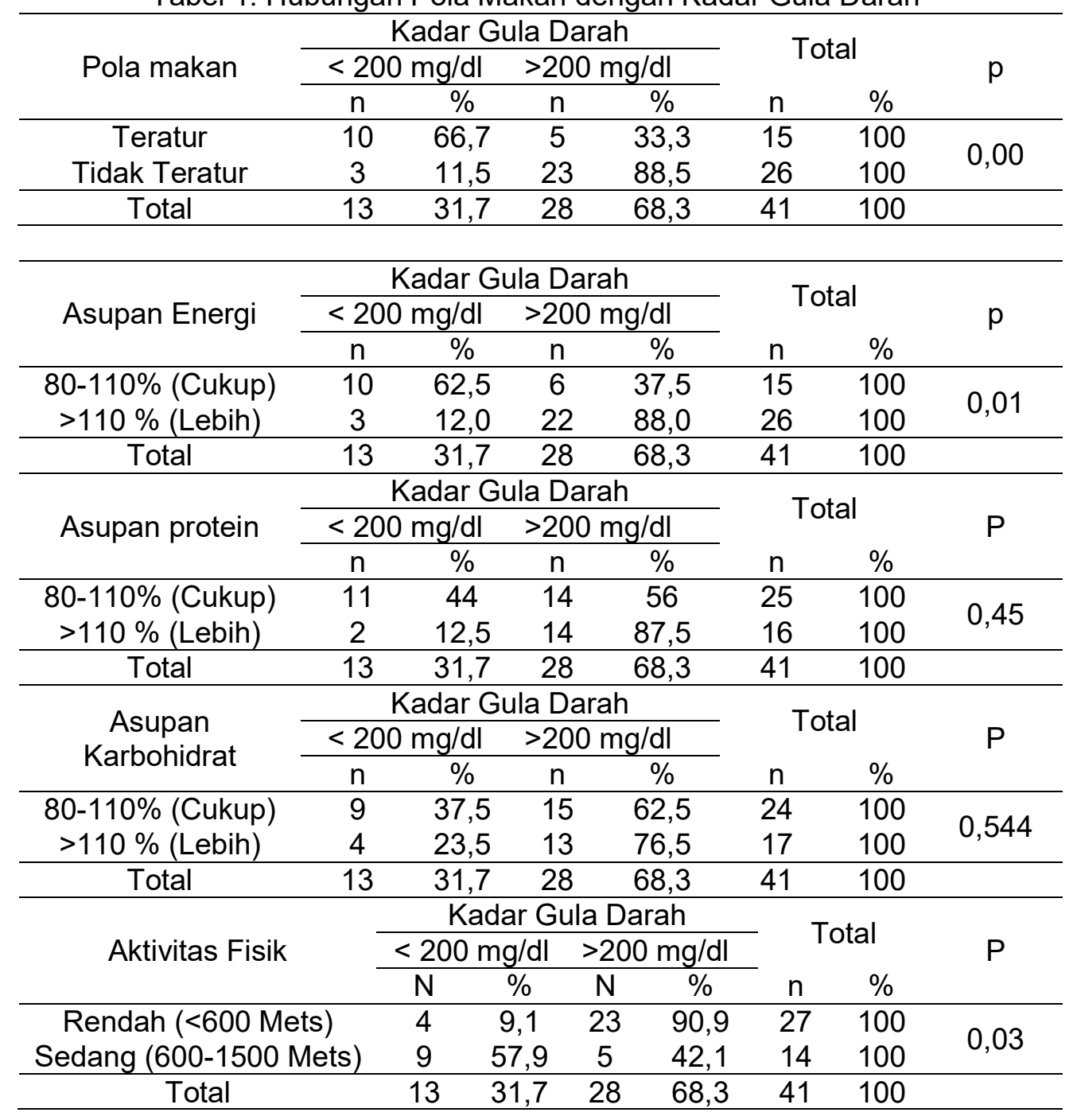

Terdapat hubungan antara pola makan teratur dengan kadar gula darah, dan adanya hubungan antara asupan energi dengan kadar gula darah $(p<0,05)$. Kemudian menunjukkan tidak adanya hubungan antara asupan protein dengan kadar gula darah. 


\section{GIZIDO Volume 11 No.2 November 2019 Pola Makan I Made Djendra dkk}

Akan tetapi, tidak adanya hubungan antara asupan lemak dengan kadar gula darah serta tidak adanya hubungan antara asupan karbohidrat dengan kadar gula darah. Kemudian, hal ini menunjukkan adanya hubungan antara aktivitas fisik dengan kadar gula darah.

\section{PEMBAHASAN}

Berdasarkan hasil analisis karakteristik sampel berdasarkan umur, sampel terbanyak memiliki umur $60-69$ tahun $(41,5 \%)$ sedangkan yang paling sedikit memiliki umur diatas 70 tahun dengan jumlah 1 orang. Sedangkan, berdasarkan jenis kelamin, sampel yang berjenis kelamin laki-laki berjumlah 15 orang $(36,6 \%)$ dan berjenis kelamin perempuan berjumlah 26 orang $(63,4 \%)$.

Berdasarkan hasil analisis karakteristik sampel berdasarkan pendidikan, sampel terbanyak berdasarkan pendidikan yaitu lulusan SMA/SMK dengan jumlah 14 orang $(34,1 \%)$ dan yang paling sedikit yaitu lulusan perguruan tinggi dengan jumlah 5 orang $(12,2 \%)$, dan karakteristik sampel berdasarkan pekerjaan, sampel terbanyak berdasarkan pekerjaan yaitu ibu rumah tangga (IRT) dengan jumlah 18 orang (43,9\%) dan yang paling sedikit memiliki pekerjaan sebagai buruh dengan jumlah 2 orang $(4,9 \%)$.

Berdasarkan hasil analisis karakteristik sampel berdasarkan kadar gula darah, sampel yang memiliki kadar gula darah $<200 \mathrm{mg} / \mathrm{dl}$ (normal) berjumlah 13 orang $(31,7 \%)$ dan sampel yang memiliki kadar gula darah $>200 \mathrm{mg} / \mathrm{dl}$ (lebih) berjumlah 28 orang $(68,3 \%)$. Kemudian sampel yang memiliki pola makan teratur ada 10 orang $(66,7 \%)$ memiliki kadar gula darah normal atau $<200 \mathrm{mg} / \mathrm{dl}$ sedangkan pada sampel yang memiliki kadar gula darah lebih atau $>200 \mathrm{mg} / \mathrm{dl}$ berjumlah 5 orang $(33,3 \%)$. Sedangkan 26 orang sampel yang memiliki pola makan tidak teratur ada 23 orang $(88,5 \%)$ yang memiliki kadar gula darah lebih atau $>200 \mathrm{mg} / \mathrm{dl}$,sedangkan pada sampel yang memiliki kadar gula darah normal atau $<200 \mathrm{mg} / \mathrm{dl}$ berjumlah 3 orang $(11,5 \%)$

Hasil uji Fisher menunjukkan bahwa $p$-value 0,00 jadi $p$-value $<0,05$. Hal ini menunjukkan adanya hubungan antara pola makan dengan kadar gula darah pasien Diabetes melitus Tipe 2, yang berarti hipotesin $\mathrm{H} 1$ diterima dan Ho ditolak. Hal ini didukung oleh penelitian yang dilakukan oleh Susanti dan Difran (2018) bahwa penelitian tersebut menunjukan adanya hubungan antara pola makan dengan kadar gula darah pada penderita Diabetes Melitus dengan hasil uji Spearman $p=0,00$.

Pada penelitian yang dilakukan oleh Nur. A., dkk (2016) bahwa pola makan makanan manis, asin dan berlemak berhubungan secara signifikan dengan kejadian Diabetes melitus. Pada 22 orang sampel yang memiliki aktivitas fisik rendah ada 2 orang $(9,1 \%)$ memiliki kadar gula darah normal atau $<200 \mathrm{mg} / \mathrm{dl}$ sedangkan pada sampel yang memiliki kadar gula darah lebih atau $>200 \mathrm{mg} / \mathrm{dl}$ berjumlah 20 orang (90,9\%). Sedangkan 19 orang sampel yang memiliki pola aktivitas fisik sedang ada 8 orang $(42,1 \%)$ yang memiliki kadar gula darah lebih atau $>200 \mathrm{mg} / \mathrm{dl}$,sedangkan pada sampel yang memiliki kadar gula darah normal atau $<200 \mathrm{mg} / \mathrm{dl}$ berjumlah 11 orang $(57,9 \%)$

Terdapat hubungan antara aktivitas fisik dengan kadar gula darah pasien Diabetes melitus Tipe 2, Sejalan dengan penelitian Nurhayati dan Andrian (2017) menyatakan terdapat hubungan fisik dengan kadar gula darah pasien penderita Diabetes Melitus tipe 2.

Hasil penelitian yang dilakukan oleh Nur, dkk., (2016) menyatakan bahwa sebagian besar pasien DM melakukan aktivitas fisik sedang dan tidak pernah olahraga. Kadar glukosa pada pasien DM juga ditemukan tidak terkontrol. Pasien dengan kadar glukosa darah terkontrol hanya 1 orang yang melakukan aktivitas ringan dan olahraga 


\section{GIZIDO Volume 11 No.2 November 2019 Pola Makan I Made Djendra dkk}

kurang dari 3 kali seminggu. Namun tidak sejalan dengan penelitian Azitha. M, dkk (2018) yang menyatakan bahwa tidak terdapat hubungan signifikan antara aktivitas fisik dan olahraga dengan kadar gula darah pada pasien DM.

\section{KESIMPULAN}

Terdapat hubungan antara pola makan dan kadar gula darah pada pasien Diabetes Melitus tipe 2. Pasien yang memiliki kadar gula darah lebih memiliki pola makan tidak teratur seperti jam makan yang tidak tepat, jumlah makanan yang dikonsumsi pun tidak diatur untuk menjaga kadar gula darah tetap terjaga. Terdapat hubungan antara aktivitas fisik terhadap kadar gula darah pada pasien Diabetes Melitus karena pasien yang memiliki kadar gula darah $>200 \mathrm{mg} / \mathrm{dl}$ lebih banyak melakukan aktivitas fisik ringan dibanding dengan yang memiliki kadar gula darah $<200 \mathrm{mg} / \mathrm{dl}$ dengan $p$-value $<0,05$ yaitu 0,03 . Seperti pasien diabetes yang memiliki kadar gula darah normal melakukan aktivitas fisik lebih sering dan beberapa kali melakukan olahraga ringan, sedangkan untuk pasien dengan kadar gula darah lebih memiliki aktifitas fisik yang rendah dan sangat jarang untuk berolahraga. Pasien dianjurkan untuk bisa mengatur pola makan dan ketepatan waktu makan agar gula darah lebih terkontrol. Karena sebagian besar responden mengeluh jika kadar gula darah naik akibat dari makan yang tidak terkontrol di hari-hari sebelumnya. Pasien dianjurkan untuk lebih banyak melakukan aktivitas fisik yang ringan namun rutin baik di dalam rumah maupun diluar rumah agar kesehatan dapat terjaga.

\section{DAFTAR PUSTAKA}

Azitha, M., Aprilia. D., \& Ilham. Y.R. (2018). Hubungan Aktivitas Fisik dengan Kadar Glukosa Darah Puasa pada Pasien Diabetes Melitus yang Datang ke Poli Klinik Penyakit Dalam Rumah Sakit M. Djamil padang. Jurnal fk Unand. 7 (3:400-404)

Cholifah, N., Azizah, N., \& Indanah. (2016). Hubungan Antara Pola Makan dan Aktivitas Fisik Dengan Kadar GDS Pada Pasien Diabetes Melitus Tipe II di Puskesmas Mayong II Jepara Tahun 2015. JIIK. 7 (2: 1-11)

Derek, M.I., Rottie, J.V. \& Kallo, V. (2017). Hubungan Tingkat Stres Dengan Kadar Gula darah Pada Pasien Diabetes Melitus Tipe II di Rumah sakit Pancaran Kasih GMIM Manado. E-journal Keperawatan. 5 (1: 1-6)

Dolongseda, F.V., Masi, G.N.M. \& Bataha, Y.B. (2017). Hubungan Pola Aktivitas Fizik dan Pola Makan dengan Kadar Gula Darah pada pasien Diabetes Melitus Tipe II di Poli Penyakit Dalam Rumah Sakit Pancaran Kasih GMIM Manado. E-journal Keperawatan. 5 (1:1-8)

IDF. 2011. IDF Diabetes Atlas Fifth Edition, International Diabetes Federation 2011. http://www.idf.org/sites/default/files/EN_5E_Atlas_Full_0.pdf diakses 08 April 2018.

IDF. 2015. IDF Diabetes Atlas Seventh Edition, International Diabetes Federation 2015. http://www.idf.org/sites/default/files/EN_7E_Atlas_Full_0.pdfdiakses 01 Mei 2018.

Kementerian Kesehatan RI. (2014). INFODATIN Pusat Data dan Informasi Kementerian Kesehatan RI. Situasi dan Analisi Diabetes.

Kurniawaty, E. \& Yanita B. (2016). Faktor-faktor Yang Berhubungan dengan Kejadian Diabetes Melitus. Majority. 5(1:27-31)

Kurniadi, H. dan Nurrahmi, U. (2014). STOP! Diabetes, Hipertensi, Kolesterol Tinggi, Jantung Koroner. Istana Media. Yogyakarta 


\section{GIZIDO Volume 11 No.2 November 2019 Pola Makan I Made Djendra dkk}

Martins W.H.B., Sutriningsih A., \& Dewi N. (2018). Pengaruh Konseling Aktivitas Fisik dan Pola Makan Terhadap Perubahan IMT Pada Penderita Diabetes Mellitus Di Puskesmas Dinoyo Kecamatan Lowokwaru Kota Malang. Nursing News. 3(1:191203)

Nur, A., Wilya, V., Ramadhan, R. (2016). Kebiasaan Aktivitas Fisik Pasien Diabetes Mellitus Terhadap Kadar Gula Darah Di Rumah Sakit Umum dr. Fauziah Bireuen, Sel Jurnal Penelitian Kesehatan. 3 (2:41-48).

Nur.A., Fitria E., Zulhaida. A., \& Hanum. S. (2016). Hubungan Pola Konsumsi dengan Diabetes Melitus Tipe 2 pada Pasien Rawat Jalan di RSUD Dr. Fauziah Bireuen Provinsi Aceh. Media Litbangkes. 26(3:145-150)

Nurhayati \& Adrian. (2017). Hubungan Aktifitas Fisik dengan Kadar Gula Darah Puasa Penderita Diabetes Melitus Tipe 2, Amerta Nutrition. 1(1:80-87)

Riset Kesehatan Dasar (Riskesdas). (2013). Kecenderungan Prevalensi DM Berdasarkan Wawancara pada Umur $\geq 15$ tahun Menurut Provinsi Sulawesi Utara. Litbangkes. Jakarta

Rizani, H.K., Suroto, \& Rizani, A. (2014) Hubungan Dukungan Keluarga Dengan Ketaatan Pola makan Penderita Diabetes melitus Di Wilayah Kerja Puskesmas Sei Besar Banjarbaru. Jurnal Skala Kesehatan. 5(2: 1-5)

Sam, N., Lestari, H. \& Afa, J.R. (2017). Analisis Hubungan Activity Daily Living (ADL), Aktivitas Fisik dan Kepatuhan Diet Terhadap Kadar Gula Darah Pasien Diabetes Melitus di Wilayah kerja Puskesmas Poasia Tahun 2017. JIMKESMAS . 2 (7:1-12)

Shahab, A. (2017). Dasar-dasar Endokrinologi. RAYYANA Komunikasindo. Jakarta

Sihombing, M. \& Tuminah, S. (2015) Hubungan Komponen Sindrom Metabolik Dengan Risiko Diabetes Melitus Tipe 2 di Lima Kelurahan Kecamatan Bogor Tengah. Media Litbangkes. 25 (4:219-226)

Siswanto, Susila dan Suyanto. (2014). Metodologi Penelitian Kesehatan dan Kedokteran. Bursa IImu. Yogyakarta

Suhaema, Sulendri, N.K.S. \& Septiana, T. (2015). Gambaran Riwayat Pola Makan Dan Status Gizi Pasien Diabetes Melitus Tipe 2 Rawat Jalan Peserta Jaminan Kesehatan Masyarakat (JAMKESMAS) di Rumah Sakit Umum Daerah Kota Mataram. Jurnal Kesehatan Prima. 9(1:1444-1456)

Suiraoka, IP. (2012). Penyakit Degeneratif. Nuha Medika. Yogyakarta

Sumangkut, S., Supit, W. \& Onibala, F. (2013). Hubungan Pola Makan Dengan Kejadian Penyakit Diabetes Melitus Tipe 2 di Poli Interna BLU.RSUP.PROF. DR. R. D. Kandou Manado. E-Journal Keperawatan. 1(1:1-6)

Susanti, \& Bistara, D.N. (2018). Hubungan Pola Makan Dengan Kadar Gula Darah Pada penderita Diabetes Melitus. Jurnal Kesehatan Vokasional. 3(1:29-34)

Syamsiyah, N. (2017). Berdamai Dengan Diabetes. Bumi Medika. Jakarta

Tandra, H.(2015). Diabetes Bisa Sembuh: petunjuk Praktis Mengalahkan dan Menyembuhkan Diabetes Gramedia. Jakarta

Tandra, H. (2017). Segala sesuatu yang harus Anda ketahui tentang Diabetes. Gramedia. Jakarta 